\title{
The content of selected vitamins and iodine in mare's milk
}

\author{
Pavlína Navrátilová, Ivana Borkovcová, Lenka Kaniová, Sandra Dluhošová, \\ Hana Zachovalová
}

\begin{abstract}
University of Veterinary and Pharmaceutical Sciences Brno,
Faculty of Veterinary Hygiene and Ecology, Department of Milk Hygiene and Technology, Brno, Czech Republic
\end{abstract}

Received February 27, 2019
Accepted October 29, 2019

\begin{abstract}
The aim of the study was to contribute to scarce literature data on the content of selected vitamins and iodine in mare's milk. The study focused on the content of selected lipophilic vitamins $(A, E)$, hydrophilic vitamins $\left(B_{1}, B_{2}, B_{6}\right)$ and iodine in milk samples obtained from 8 mares during 6 months of lactation. The content of micronutrients was evaluated according to the stage of lactation. Vitamins $\mathrm{B}_{2}$ and $\mathrm{B}_{6}$ were determined using ion-pair reversed phase high performance liquid chromatography with fluorescence detection, vitamin $\mathrm{B}$ by fluorescence detection by reversed-phase liquid chromatography, vitamins $\mathrm{A}$ and $\mathrm{E}$ by the ultra-high performance liquid chromatography method with ultraviolet and fluorescence detection and iodine by the spectrophotometric method. Mean concentrations of vitamins A $(0.06 \pm 0.08 \mathrm{mg} / \mathrm{l})$, $\mathrm{E}(0.083 \pm 0.14 \mathrm{mg} / \mathrm{l}), \mathrm{B}_{1}(256.24 \pm 44.19 \mu \mathrm{g} / \mathrm{l}), \mathrm{B}_{2}(111.40 \pm 81.88 \mu \mathrm{g} / \mathrm{l}), \mathrm{B}_{6}(0.30 \pm 0.12 \mathrm{mg} / \mathrm{l})$ reached lower values in mare's milk compared to cow's milk. The mean value of iodine in mare's milk reached $44.48 \pm 54.45 \mu \mathrm{g} / 1$. Lactation stage proved to be a significant factor for vitamin $\mathrm{B}_{6}$ and iodine.
\end{abstract}

Equid milk, minor nutrients, lactation stage

Milk is a complex foodstuff containing a number of nutritionally important substances. Milk composition varies considerably from species to species in relation to genetic, physiological and nutritional factors and also to environmental conditions (Malacarne et al. 2002; Weaver et al. 2013). Milk and dairy products contribute considerably not only to the intake of energy and macronutrients, but they are also an important source of minor nutrients - minerals and vitamins. Milk and dairy products provide about $1 / 3$ of the recommended intake of riboflavin. The intake of thiamine is also dependent on the consumption of dairy products. Dairy products contribute to covering the need for B-group vitamins, namely vitamin $\mathrm{B}_{6}$, vitamin $\mathrm{B}_{12}$, and folic acid. Dairy products also considerably affect the vitamin A intake. Milk contains both vitamin A and carotenoids. However, the presence of these compounds is linked to milk fat, resulting in lower levels of vitamin A and carotenoids in low-fat milk (Barker 2002). Milk contains all the essential mineral elements. However, the amount of macro- and micro-elements in milk is influenced by a number of factors; such as the content of elements in the soil and subsequently in the feed. Therefore, the mineral content in milk varies significantly between countries as well as within the countries themselves (Zamberlin et al. 2012).

Iodine supply is still a broadly discussed topic, and it is a global serious issue. Up to 2 billion people in the world live in conditions of insufficient iodine saturation. Iodine is part of the thyroid hormones: thyroxine and triiodothyronine. Deficiency of iodine in food has an adverse effect on the growth and development of human organism. These effects are due to inadequate production of thyroid hormone and are termed as Iodine Deficiency Disorders (IDD) (Zimmermann 2008). Milk and dairy products are an important source of iodine in industrially developed countries (Van Der Reijden et al. 2017).

Address for correspondence: 
Data on the content of minor nutrients in mare's milk are not commonly found and largely differ in literature. This may be due to the fact that production of mare's milk is a rather local issue with a large variability in the content of ingredients influenced by a number of factors (breed, nutrition, lactation stage, feeding regime, etc.). The above mentioned factors are also the cause of high variability in the vitamin content of mare's milk. The vitamin content in mare's milk is on average lower than in milk of ruminants. The exception is vitamin C, the content of which is relatively high in mare's milk. The content of hydrophilic vitamins is influenced by nutrition more than the content of lipophilic ones, the content of which depends on the level of fat in milk. Mare's milk contains considerably less fat than ruminant milk, and therefore, the content of lipophilic vitamins is lower (Claeys et al. 2014; Pieszka et al. 2016).

Mare's milk is an important and traditional foodstuff of animal origin in some Asian countries. Moreover, the interest in mare's milk and its use in human nutrition has been increasing in some European countries (Netherlands, Belgium, Norway, France). Specific therapeutic properties are attributed to mare's milk, and it has long been used to treat a number of diseases in countries with its traditional production. Since mare's milk composition is more similar to human milk than ruminant milk, it is considered to be a suitable alternative to human milk. Mare's milk is used for the production of dairy products (kumis) as well as in the cosmetic industry or for production of food supplements (Park et al. 2006; Pieszka et al. 2016).

The aim of the study was to contribute to the scarce data on the content of selected minor nutrients in mare's milk. The study focused on the content of selected lipophilic vitamins tocopherol (vitamin E), retinol (vitamin A), hydrophilic vitamins thiamine (vitamin $B_{1}$ ), riboflavin (vitamin $\mathrm{B}_{2}$ ), pyridoxine (vitamin $\mathrm{B}_{6}$ ), and iodine. The content of minor nutrients was evaluated according to the lactation stage.

\section{Milk samples}

\section{Materials and Methods}

Samples of mare's milk were obtained from 8 warmblood breeding mares. Samples (at least $500 \mathrm{ml}$ ) were obtained manually within 6 months of delivery at a sampling frequency of once per month. A total of 48 samples were collected and tested. Mares were fed with a standard feed dose during lactation (Table 1). In addition to hay, it contained oats and complementary feed. Over the first six months of lactation, the feed dose comprised the following: months 1-4: $3 \mathrm{~kg}$ oats $+3 \mathrm{~kg}$ granules; month 5: $3 \mathrm{~kg}$ oats $+3 \mathrm{~kg}$ feed supplement; month 6: $2 \mathrm{~kg}$ oats $+2 \mathrm{~kg}$ granules. The basal diet was formulated following animal nutrient requirements (National Research Council 1989). Animal handling followed the EU Directive 2010/63/EU regarding animal care. Milk samples were collected from mares on a farm in the South Moravian region. After milking, the samples were chilled to 4- $6^{\circ} \mathrm{C}$ and transported to the lab. They were stored at this temperature until tested. If the tests were not carried out within $48 \mathrm{~h}$ from milking, the milk samples were frozen to $-18^{\circ} \mathrm{C}$ and stored until they were removed for testing.

Methods

Methods for determination $\mathrm{B}_{1}, \mathrm{~B}_{2}$ and $\mathrm{B}_{6}$ were introduced, developed and modified in our laboratory according to $\mathrm{Ndaw}$ et al. (2000) with regard to the properties of milk samples. Each analysis was made in at least duplicate.

Determination of vitamins $\mathrm{B}_{2}$ and $\mathrm{B}_{6}$

Riboflavin and pyridoxine were determined in a supernatant after fat removal and protein precipitation with $10 \%$ acetic acid up to $\mathrm{pH} 4.2$ using ion-pair reversed phase high performance liquid chromatography (IP-RP-HPLC) with fluorescence detection.

Ten $\mathrm{ml}$ of milk sample were centrifuged for $10 \mathrm{~min}$ at $4,193 \times g$ and $5{ }^{\circ} \mathrm{C}$. After removing the upper fatty layer, $10 \%$ acetic acid was slowly added to the sample while stirring until $\mathrm{pH}$ reached 4.2 . The reaction mixture was centrifuged for $5 \mathrm{~min}$ at $4,193 \times g$ and $5{ }^{\circ} \mathrm{C}$, and about $2 \mathrm{ml}$ of the supernatant were filtered through a 0.45 or $0.22 \mu \mathrm{m}$ nylon filter into HPLC vials.

Riboflavin assay was performed on a fluorescence detector at $\lambda$ ex $/ \lambda \mathrm{em}=450 / 520 \mathrm{~nm}$ wavelengths; pyridoxine at $\lambda$ ex $/ \lambda$ em $=290 / 395 \mathrm{~nm}$ wavelengths. For separation, a Zorbax Eclipse XDB C8 chromatographic column (Agilent, USA), $4.6 \times 150 \mathrm{~mm}, 5 \mu \mathrm{m}$ was used. The column temperature was $35^{\circ} \mathrm{C}$, at spray rate of $10 \mu \mathrm{l}$. The assay was performed in a gradient elution mode, mobile phase A was an aqueous solution of the ionic pairing agent, acetic acid and triethylamine in a ratio of $5 \mathrm{mmol}: 1 \%: 0.13 \%$. Mobile phase B was acetonitrile. A linear gradient of 95 to $82 \%$ of mobile phase $\mathrm{A}$ at a flow rate of $0.7 \mathrm{ml} / \mathrm{min}$ was applied. 
Table 1. Composition of granules and feed supplements as reported by the producer.

\begin{tabular}{|c|c|c|}
\hline Specification & Feed & \\
\hline Name & Granules & Feed supplement I \\
\hline \multirow[t]{4}{*}{ Composition } & $\begin{array}{l}\text { Wheat bran, malt flour, oats, alfalfa powder, } \\
\text { sugar beet pulps, barley, maize, } \\
\text { beet molasses, calcium carbonate, } \\
\text { sodium chloride, vitamins, trace elements }\end{array}$ & $\begin{array}{l}\text { Oats, barley, alfalfa powder, wheat germs, } \\
\text { wheat bran, lysine, dried sugar beet pulp, } \\
\text { apple pomace, feed salt, vitamins, trace } \\
\text { elements }\end{array}$ \\
\hline & \multicolumn{2}{|l|}{ Vitamins per kg } \\
\hline & $13,900 \mathrm{IU}$ vitamin $\mathrm{A}$ & 1,050 IU vitamin D \\
\hline & $1,200 \mathrm{IU}$ vitamin $\mathrm{D}_{3}$ & $128 \mathrm{mg}$ vitamin $\mathrm{E}$ \\
\hline \multicolumn{3}{|c|}{ Trace elements per $\mathrm{kg}$} \\
\hline (E 4) Copper & $10 \mathrm{mg}$ & $25.16 \mathrm{mg}$ \\
\hline (E 1) $\mathrm{Fe}$ & $200 \mathrm{mg}$ & \\
\hline (E 5) Manganese & $240 \mathrm{mg}$ & $40 \mathrm{mg}$ \\
\hline (E6) Zinc & $250 \mathrm{mg}$ & $124 \mathrm{mg}$ \\
\hline Cobalt & $1.1 \mathrm{mg}$ & $0.33 \mathrm{mg}$ \\
\hline Iodine & $3.4 \mathrm{mg}$ & $0.42 \mathrm{mg}$ \\
\hline Selenium & $1.2 \mathrm{mg}$ & $0.26 \mathrm{mg}$ \\
\hline Magnesium & - & $205 \mathrm{mg}$ \\
\hline \multicolumn{3}{|c|}{ Analytical components per $\mathrm{kg}$} \\
\hline Crude protein & $14.6 \%$ & Nitrogen compounds $130 \mathrm{~g}$ \\
\hline Crude fibre & $11.20 \%$ & Crude fibre $105 \mathrm{~g}$ \\
\hline Crude oils and fats & $2.7 \%$ & Dry matter $900 \mathrm{~g}$ \\
\hline Crude ash & $8.4 \%$ & Digestible energy $11.54 \mathrm{MJ}$ \\
\hline Calcium & $1.3 \%$ & Calcium $5.88 \mathrm{~g}$ \\
\hline Phosphorus & $0.6 \%$ & Phosphorus $4.19 \mathrm{~g}$ \\
\hline Sodium & $0.3 \%$ & $\begin{array}{l}\text { Sodium } 2.67 \mathrm{~g} \\
\text { Lysine } 9.71 \\
\text { Dry matter } 900 \mathrm{~g} \\
\text { DCPh } 97 \mathrm{~g} \\
\mathrm{Cu} \text { (chelate) } 15 \mathrm{~g} \\
\mathrm{Zn} \text { (chelate) } 35 \mathrm{~g}\end{array}$ \\
\hline
\end{tabular}

DCPh - Digestible Crude Protein horse, IU - international unit

Determination of vitamin $\mathrm{B}_{1}$

Thiamine, including its phosphorylated forms, is determined by reversed-phase liquid chromatography (RP-HPLC) with fluorescence detection after acid and enzymatic hydrolysis and conversion to thiochrome.

Ten $\mathrm{ml}$ of milk were put into a $150 \mathrm{ml}$ beaker, after adding $50 \mathrm{ml}$ of $\mathrm{HCl}(c=0.1 \mathrm{~mol} / \mathrm{l})$ the sample was incubated in a water bath at $60^{\circ} \mathrm{C}$ for $30 \mathrm{~min}$. After cooling to room temperature, the $\mathrm{pH}$ of the reaction mixture was adjusted to 4.5 with sodium acetate $(c=2.5 \mathrm{~mol} / \mathrm{l})$. Then the sample was quantitatively transferred to a $250 \mathrm{ml}$ Erlenmeyer flask, $1 \mathrm{ml}$ of aqueous suspension of Clara Diastase enzyme was added $(0.250 \mathrm{~g}$ Clara Diastase enzyme mixture suspended in $1 \mathrm{ml}$ deionized water). The sample was incubated for about $16 \mathrm{~h}$ at $37^{\circ} \mathrm{C}$ with constant stirring. After cooling to room temperature, the mixture was transferred to a $100 \mathrm{ml}$ volumetric flask and the volume was made up to the mark with water.

After the enzymatic hydrolysis, $1 \mathrm{ml}$ of the solution was taken up in a $15 \mathrm{ml}$ tube, $1 \mathrm{ml}$ of derivatizing agent was added ( $2 \mathrm{ml}$ of $1 \%$ potassium ferricyanide solution were added to $50 \mathrm{ml}$ of $15 \% \mathrm{KOH}$ solution). The derivatizing agent was prepared fresh immediately prior to derivatization. The reaction mixture was stirred for $10 \mathrm{~s}$. After $1 \mathrm{~min}, 1.5 \mathrm{ml}$ of isopropanol/isobutanol was added and, after stirring $(15 \mathrm{~s})$ it was allowed to stand at room temperature until the separation of the aqueous and alcohol layers. Approximately $1 \mathrm{ml}$ was taken from the top 
layer for the HPLC assay. The stability of thiochrome was limited (approx. 3-10 h), the determination had to be performed in the shortest time possible after derivation.

An Ascentis RP Amide chromatography column, $150 \times 4.6 \mathrm{~mm}, 3 \mu \mathrm{m}$ (Supelco, USA) was used for the analysis. The mobile phase had the following composition: phosphate buffer, $\mathrm{pH}$ 7.2/acetonitrile (80:20), flow rate $0.8 \mathrm{ml} / \mathrm{min}, \mathrm{Tk}=35^{\circ} \mathrm{C}$, injection volume $10 \mu \mathrm{l}$, detection at $\lambda \mathrm{ex} / \lambda \mathrm{em}=368 / 440 \mathrm{~nm}$. The evaluation was performed using the calibration curve method.

\section{Determination of lipophilic vitamins A, E}

Vitamins $A$ and $\mathrm{E}$ are determined after being released from the ester bonds by alkaline hydrolysis (saponification) and extraction of the unsaponifiable portion into a non-polar solvent by RP HPLC.

A pinch of ascorbic acid and hydroquinone, $10 \mathrm{ml}$ of methanolic $\mathrm{KOH}(1$ part of $\mathrm{KOH}(c=10 \mathrm{~mol} / \mathrm{l})+9$ parts of methanol p.a.) were added to $1 \mathrm{~g}$ of milk. The sample was saponified at $60{ }^{\circ} \mathrm{C}$ under reflux for $30 \mathrm{~min}$. After cooling, $5 \mathrm{ml}$ of deionized water and $10 \mathrm{ml}$ of hexane as an extraction agent were added to the mixture and shaken vigorously for $20 \mathrm{~min}$. After the layers separated, the maximum hexane fraction was taken and rinsed with water to neutral and dried with anhydrous sodium sulphate. Hexane was evaporated, the residue was subsequently dissolved in methanol. After filtering through a $0.22 \mu \mathrm{m}$ membrane filter, the obtained sample was analysed by the ultra-high performance liquid chromatography (UHPLC) method with ultraviolet and fluorescence detection.

For the final chromatographic assay, an Acquity BEH C8 reversed-phase column, $100 \times 2.1 \mathrm{~mm}$, $1.7 \mu \mathrm{m}$ (Waters, Ireland) was used. The mobile phase was a mixture of methanol and water (93:7), flow rate of $0.4 \mathrm{ml} / \mathrm{min}, \mathrm{Tk}=35^{\circ} \mathrm{C}$, injection volume $5 \mu \mathrm{l}$. Retinol detection was performed in the UV region at $325 \mathrm{~nm}$. For tocopherol, fluorescence detection with a pair of $\lambda \mathrm{ex} / \lambda \mathrm{em}=295 / 340 \mathrm{~nm}$ wavelengths was applied.

\section{Determination of iodine}

Iodine was determined by a spectrophotometric method based on the catalytic action of iodide ions on the oxidoreductive reaction of $\mathrm{Ce}^{4+}$ and $\mathrm{As}^{3+}$ by Sandell-Kolthoff. The course of the reaction is a function of the iodine concentration in the solution, which allows determining the iodine from the measurement of the loss of $\mathrm{Ce}^{4+}$ (Bednár et al. 1964). The catalytic reaction is terminated by the addition of brucine, which forms reddish quinoid structures with $\mathrm{Ce}^{4+}$ and their absorbance is measured spectrophotometrically at $430 \mathrm{~nm}$. The detection limit of the method is $15 \mu \mathrm{g} / \mathrm{l}$. Each analysis was made at least in duplicate.

\section{Statistical analysis}

The analysis was performed using STATISTICA 13.2 (Dell, Inc., Tulsa, OK, USA) software. Based on the results of data analysis, data sets for "vitamin A", "vitamin E", "vitamin B,"and "iodine" were transformed using the logarithmic transformation of $\mathrm{f}(\mathrm{x})=\log _{10}(\mathrm{x})$; data sets of "vitamin $\mathrm{B}_{1}$ " by Box-Cox transformation of $f(x)=\left(x^{\lambda}-1\right) / \lambda$. These transformations ensured fulfilment of ANOVA assumptions (residual normality, homogenity of scattering).

Independent variables (y): vitamin A transformation: $\log (\mathrm{A})$; vitamin $\mathrm{E}$ transformation: $\log (\mathrm{E})$; vitamin $\mathrm{B}$ not transformed; vitamin $B_{1}$ transformation: $\left.b c\left(B_{1}\right)=\left[\left(B_{1} / 100\right)^{\lambda}-1\right)\right] / \lambda, \lambda=-2.4496 ; 95 \%$ CI for $\lambda$ : -4.2379 to -0.8419 ; vitamin $\mathrm{B}_{2}$ transformation: $\log \left(\mathrm{B}_{2}\right)$; iodine transformation: $\log ($ iodine $)$

Factor (independent categorical (ordinal) variable): Month (6 levels: 1..6).

Model (one-way ANOVA):

$\mathrm{y}_{\mathrm{i}}=\mu+\alpha_{i}+\varepsilon_{\mathrm{i}}$

i-levels of factor Month (1..6); $y_{i}$-value of dependent variable on i-th level of factor Month; $\mu$-grand mean; $\alpha_{i}$-effect of $\mathrm{i}$-th level of factor Month; $\varepsilon_{\mathrm{I}}$-random errors; normally distributed $\mathrm{N}\left(0 ; \sigma^{2}\right)$.

\section{Results}

\section{Vitamins A and E}

The retinol concentration (geometric mean) in the milk samples determined in the present study was $0.06 \pm 0.08 \mathrm{mg} / \mathrm{l}$. The values fluctuated over a relatively wide range $(0.009-0.339 \mathrm{mg} / \mathrm{l})$. Statistical evaluation showed that the variation in retinol concentrations was not significant over the period of lactation $(P>0.05$; Table 2$)$. Vitamin A values tended to decrease over the lactation period. The lowest mean value $(0.049 \pm 0.080 \mathrm{mg} / \mathrm{l})$ was measured in the $6^{\text {th }}$ month of lactation. The average content (geometric mean) of tocopherol in the milk samples was $0.083 \pm 0.140 \mathrm{mg} / \mathrm{l}$, and the concentration varied over a range of $0.024-0.480 \mathrm{mg} / \mathrm{l}$. The lowest mean value $(0.030 \pm 0.003 \mathrm{mg} / \mathrm{l})$ was recorded in the $4^{\text {th }}$ month of lactation. Statistical evaluation showed that vitamin E concentrations did not vary significantly over the lactation period $(P>0.05$; Table 2$)$. 


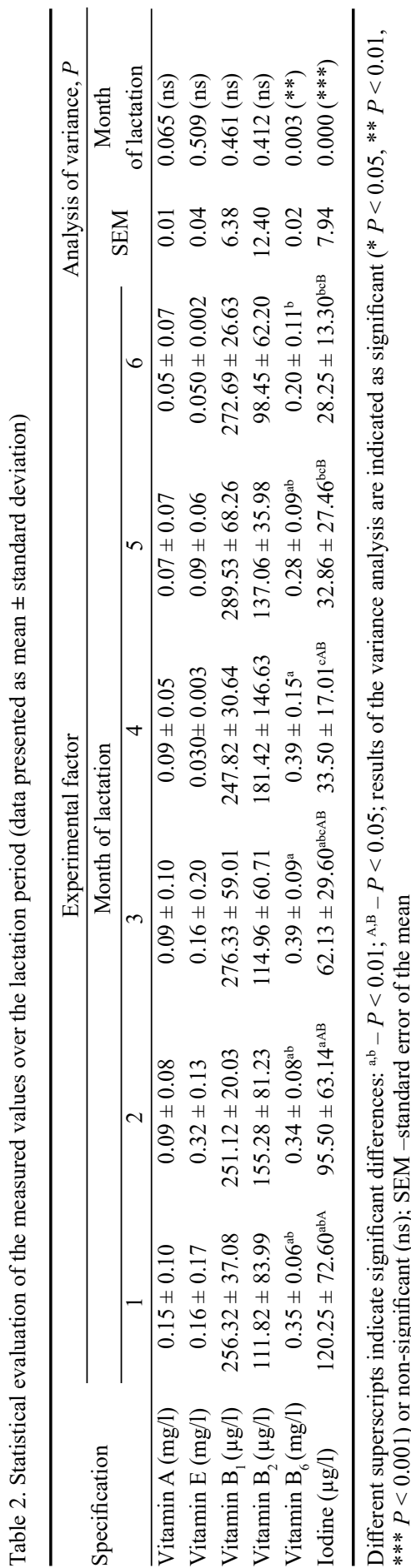

Vitamins $\mathrm{B}_{1}, \mathrm{~B}_{2}$ and $\mathrm{B}_{6}$

In our study, the mean thiamine concentration was $256.24 \pm 44.19 \mu \mathrm{g} / \mathrm{l}$. Statistical evaluation showed that thiamine concentrations did not significantly vary over the period of lactation $(P>0.05$; Table 2). The minimum and maximum concentrations of thiamin in the milk samples were 204.77 and $417.25 \mu \mathrm{g} / \mathrm{l}$, respectively. The mean value (geometric mean) of vitamin $\mathrm{B}_{2}$ in the analysed samples was $111.40 \pm 85.88 \mu \mathrm{g} / \mathrm{l}$, the measured concentrations fluctuated over a wide range (28.57-482.93 $\mu \mathrm{g} / \mathrm{l})$. There was no significant difference in vitamin $\mathrm{B}_{2}$ concentrations over the lactation period $(P>0.05$; Table 2$)$. The mean value (arithmetic mean) of pyridoxine in the analysed samples was $0.32 \pm 0.12 \mathrm{mg} / \mathrm{l}$. The vitamin $\mathrm{B}_{6}$ content in the samples tested ranged between $0.083-0.607 \mathrm{mg} / \mathrm{l}$. Statistical analysis of data confirmed that the variations in pyridoxine values were significant over time during the lactation period $(P<0.01$; Table 2$)$. Vitamin $\mathrm{B}_{6}$ levels increased slightly at the beginning of lactation, peaked in the third to fourth month of lactation, and then declined sharply. The lowest mean value of $0.20 \pm 0.11 \mathrm{mg} / \mathrm{l}$ was measured at the $6^{\text {th }}$ month of lactation with a significant $P<0.01$ ) decrease over the previous months.

\section{Iodine}

In the present study, the average iodine content (geometric mean) was $44.48 \pm 54.45 \mu \mathrm{g} / \mathrm{l}$ (Table 2). Iodine content decreased significantly $(P<0.001)$ over the entire lactation period, with $\log$ (iodine) declining by an average of 0.143 each month, which corresponds to a mean month-on-month decrease of $28.1 \%$.

\section{Discussion}

Vitamins $\mathrm{A}$ and $\mathrm{E}$

The reported concentration of retinol in mare's milk $(0.403 \mathrm{mg} / \mathrm{l})$ is similar to that in cow's milk $(0.434-0.799 \mathrm{mg} / \mathrm{l})$ but lower than in human milk $(0.455 \mathrm{mg} / \mathrm{l}$; Pieszka et al. 2016). The vitamin A content in mare's milk can fluctuate over a relatively wide range of $0.093-0.34 \mathrm{mg} / \mathrm{l}$, as reported by Salimei and Fantuz (2012). The vitamin A content was also highly variable in our study with the same peak value $(0.339 \mathrm{mg} / \mathrm{l})$. The mean retinol 
level measured in mare's milk in our study was lower than that reported by Csapó et al. (1995). They analysed the contents of vitamins $A, D_{3}, E, K_{3}$, and $C$ in the colostrum and mature milk of mares and compared them to the levels in cow's milk. They found the vitamin A content in the colostrum to be $2.6 \times$ higher than in mare's milk. The average in mare's milk over 8-45 days of lactation was $0.34 \mathrm{mg} / \mathrm{kg}$ and was close to that found in cow's milk, $0.352 \mathrm{mg} / \mathrm{kg}$. However, in our study the vitamin A contents in the $5^{\text {th }}$ and $6^{\text {th }}$ months $(0.07$ and $0.05 \mathrm{mg} / \mathrm{l})$ were lower than those reported by Markiewicz-Kęszycka et al. (2014), who monitored the content of fat-soluble vitamins in mare's milk late in the lactation period (141-210 days after birth). The vitamin A content fluctuated over a range of $0.21-0.51 \mathrm{mg} / \mathrm{l}$; the average was $0.403 \pm 0.081 \mathrm{mg} / \mathrm{l}$. The study by Schweigert and Gottwald (1999) highlighted the significant variation of retinol content in milk over the lactation period. The highest values were measured immediately after birth, nevertheless, followed by a significant $(P<0.01)$ decrease just 2 days later. The retinol content in the colostrum was $2.8 \times$ higher than in milk 21 days after birth. These studies (Schweigert and Gottwald 1999; Markiewicz-Kęszycka et al. 2014) demonstrated a significant effect of lactation (especially in the postpartum period) on retinol levels in colostrum and milk. Our results showed that the highest value in the 6 month-period was recorded in the first month of lactation (Table 2). Levels of vitamin A gradually decreased during the 6 months and the lowest concentrations of both vitamins were measured in the $6^{\text {th }}$ month of lactation (Table 2). No significant effect variation was recorded in our study but the study did not compare the vitamin concentrations in colostrum and milk.

Vitamin E, together with vitamin A, is the most abundant lipophilic vitamin in mare's milk $(26-113 \mu \mathrm{g} / 100 \mathrm{ml}$; Claeys et al. 2014). In cow's milk, the content is similar $(20-184 \mu \mathrm{g} / 100 \mathrm{ml})$, while in human milk it is noticeably higher $(300-800 \mu \mathrm{g} / 100 \mathrm{ml}$; Claeys et al. 2014). Information about the vitamin E content in mare's milk in literature is variable. Markiewicz-Kęszycka et al. (2014) found a much higher average $(1.13 \pm 0.27 \mathrm{mg} / \mathrm{l})$ for tocopherol in mare's milk in late lactation. Higher values were also published by Csapó et al. (1995); their study did not confirm a significant difference in the vitamin E content in colostrum and milk at the beginning of lactation (1.342 and 1.128 $\mathrm{mg} / \mathrm{kg}$, respectively). In contrast, the study by Schweigert and Gottwald (1999) showed that vitamin $\mathrm{E}$ concentration varied significantly over the lactation period. The vitamin $\mathrm{E}$ content was highest in the colostrum $(1668 \pm 336 \mathrm{ng} / \mathrm{ml})$, and it decreased significantly $(834 \pm 164 \mathrm{ng} / \mathrm{ml}, P<0.05)$ in 2 days; it was even lower $395 \pm 67 \mathrm{ng} / \mathrm{ml}$ on the $42^{\text {nd }}$ postpartum day. Based on the statistical evaluation of results in our study, we can conclude that the vitamin E content did not vary significantly over the lactation period. The present study did not include colostrum analysis.

Vitamins $\mathrm{B}_{1}, \mathrm{~B}_{2}$, and $\mathrm{B}_{6}$

Very few studies have been published on B-group vitamin contents in mare's milk and they are rather outdated (Holmes et al. 1946; Pearson 1947; Marconi and Panfili 1998). These studies have been cited by many current articles and reviews. Milk is one of the most important sources of thiamine (Velíšek and Hajšlová 2009). In human milk, the content of vitamin $B_{1}$ is lower (140-170 $\left.\mu \mathrm{g} / \mathrm{l}\right)$ than in cow's milk (280-900 $\mu \mathrm{g} / \mathrm{l}$; Claeys et al 2014). The content of thiamine determined by Pearson (1947) was lower $(160 \mu \mathrm{g} / \mathrm{l})$ than our results as well as that reported by Holmes et al. (1946; $390 \mu \mathrm{g} / \mathrm{l})$. Claeys et al. (2014) report thiamine content in mare's milk ranging between 200-400 $\mu \mathrm{g} / \mathrm{l}$. Our results confirmed that the thiamine concentration is within that range.

It is estimated that almost $40 \%$ of the vitamin $\mathrm{B}_{2}$ intake through food comes from milk and dairy products (Velíšek and Hajšlová 2009). A review published by Claeys et al. (2014) shows that the riboflavin concentration is higher in cow's milk (116-202 $\mu \mathrm{g} / 100 \mathrm{ml})$ than in mare's milk (10-37 $\mu \mathrm{g} / 100 \mathrm{ml})$. Consuming $100 \mathrm{ml}$ of mare's milk only covers $3 \%$ 
of the recommended daily dose of vitamin $\mathrm{B}_{2}$ for an adult. The observed mean value of vitamin $\mathrm{B}_{2}$ level in mare's milk was lower than the value $(400 \mu \mathrm{g} / \mathrm{l})$ published by Pearson (1947). Holmes et al. (1946) observed vitamin $B_{2}$ in mare's milk (111 $\left.\mu \mathrm{g} / \mathrm{l}\right)$ at similar levels as our results.

In milk, about $10 \%$ of the vitamin $\mathrm{B}_{6}$ is bound to protein and its level is relatively low (Velíšek and Hajšlová 2009). Comparing published data on pyridoxine concentration in mare's milk $(30 \mu \mathrm{g} / 100 \mathrm{ml})$ with other types of milk, we see that the concentration in human milk is relatively low $(11-14 \mu \mathrm{g} / 100 \mathrm{ml})$, but higher concentrations are reported in bovine milk (30-70 $\mu \mathrm{g} / 100 \mathrm{ml})$. Consumption of $100 \mathrm{ml}$ of mare's milk covers only $2 \%$ of the recommended daily dose of pyridoxine in an adult human (Claeys et al. 2014). The content of pyridoxine in our study of mare's milk was similar to those published by Claeys et al. (2014).

\section{Iodine}

The content of iodine in products of animal origin depends on the level of the element in the feed, possibly on iodine supplementation to the feed and on the use of iodine-containing veterinary medicinal products. The recommended daily dose of iodine issued by the WHO for adults is $150 \mu \mathrm{g}$ (Van Der Reijden et al. 2017). It is known that supplementation of animal feed with iodine influences the iodine content in milk. From the feed composition data (Table 1) the derived daily dose of iodine in the feed (without taking into account the amount of iodine consumed in green fodder) was approximately $13.6 \mathrm{mg}$. Literature provides copious data on the iodine content in bovine, goat, sheep, and human milk (Barłowska et al. 2011). The iodine concentration in mare's milk is mentioned only in some outdated studies. According to these studies carried out in the 1970s and 1980s, the iodine concentration in mare's milk ranges from 0.4-4.2 $\mu \mathrm{g} / 100 \mathrm{~g}$ (Doreau and Boulot 1989). The authors believe the main factors influencing iodine concentration are the intake of iodine through feed and the amount of milk produced. The concentration was slightly lower than the concentration found in our study.

In conclusion, our study confirmed that the mean concentrations of the analysed vitamins A, E, $\mathrm{B}_{1}, \mathrm{~B}_{2}, \mathrm{~B}_{6}$ are lower in mare's milk than in cow's milk. Among these, only the levels of vitamin $\mathrm{B}_{6}$ and iodine varied significantly over the lactation period.

\section{Acknowledgements}

We thank the graduate students T. Kubíková, S. Horáková and J. Iwanuszková for their assistance in chemical analyses of samples. This work was supported by the Internal Grant Agency of the University of Veterinary and Pharmaceutical Sciences Brno [Grant no. 203/2016/FVHE].

\section{References}

Barker ME 2002: Nutritional role of dairy products /Contribution of dairy foods to nutrient intake. In: Roginski HJ, Fuquay W, Fox PF (Eds): Encyclopedia of Dairy Sciences. $1^{\text {st }}$ ed. Elsevier Ltd., London, pp. 2133-2137

Barłowska J, Szwajkowska M, Litwińczuk Z 2011: Nutritional value and technological suitability of milk from various animal species used for dairy production. Compr Rev Food Sci F 10: 291-302

Bednář J, Röhling S, Vohnout S 1964: Př́íspěvek ke stanovení proteinového jodu v krevním séru (Contribution to the determination of protein iodine in blood serum) (In Czech). Československá farmacie 13: 203-209

Claeys WL, Verraes C, Cardoen S, De Block J, Huyghebaert A, Raes K, Dewettinck K, Herman L 2014 : Consumption of raw or heated milk from different species: An evaluation of the nutritional and potential health benefits. Food Control 42: 188-201

Csapó J, Stefler J, Martin TG, Makray S, Csapó- Kiss Z 1995: Composition of mares' colostrums and milk. Fat content, fatty acids composition and vitamin content. Int Dairy J 5: 393-402

Directive 2010/63/EU of the European Parliament and of the Council of 22 September 2010 on the protection of animals used for scientific purposes. OJ L 276: 33-79

Doreau M, Boulot S 1989: Recent knowledge on mare milk production: a review. Livest Prod Sci 22: 213-235

Holmes AD, McKey BV, Wertz AW, Lindquist HG, Parkinson LR 1946: The vitamin content of mare's milk. J Dairy Sci 29: 163-171 
Malacarne M, Martuzzi F, Summer A, Mariani P 2002: Protein and fat composition of mare's milk: some nutritional remarks with reference to human and cow's milk. Int Dairy J 12: 869-877

Marconi E, Panfili G 1998: Chemical composition and nutritional properties of commercial products of mare milk powder. J Food Compos Anal 11: 178-187

National Research Council 1989: Nutrient Requirements of Horses. $5^{\text {th }}$ edn. The National Academies Press, Washington, DC, $112 \mathrm{p}$.

Markiewicz-Kęszycka M, Wójtowski J, Gryżak-Runowska G, Kuczyńska B, Puppel K, Krzyżewski J, Strzałkowska N, Jóźwik A, Bagnicka E 2014: Concentration of selected fatty acids, fat-soluble vitamins, and b-carotene in late lactation mares' milk. Int Dairy J 38: 31-36

Ndaw S, Bergaentzlé M, Aoudé-Werner D, Hasselmann C 2000: Extraction procedures for the liquid chromatographic determination of thiamin, riboflavin and vitamin B in foodstuffs. Food Chem 71: 129-138

Park YW, Zhang H, Zhang B, Zhang L 2006: Mare milk. In: Park YW, Haenlaein GFW (Ed.): Handbook of milk of non-bovine mammals. $1^{\text {st }}$ edn. Blackwell Publishing Ltd., London, pp. 275-296

Pearson PB 1947: The thiamine, riboflavin, nicotinic acid, and pantothenic acid contents of mare's colostrum and milk and ascorbic acid content of the milk. J Dairy Sci 30: 73-77

Pieszka M, Łuszczyński J, Zamachowska M, Augustyn R, Długosz B, Hędrzak M 2016: Is mare milk an appropriate food for people? - A review. Ann Anim Sci 16: 33-51

Salimei E, Fantuz F 2012: Equid milk for human consumption. Int Dairy J 24: 130-142

Schweigert FJ, Gottwald C 1999: Effect of parturition on levels of vitamins A and E and of $\beta$-carotene in plasma and milk of mares. Equine Vet J 31: 319-323

Van Der Reijden OL, Zimmermann MB, Galetti V 2017: Iodine in dairy milk: sources, concentrations and importance to human health. Best Pract Res Clin Endocrinol Metab 31: 385-395

Velíšek J, Hajšlová J 2009: Chemie potravin I (Food Chemistry I) (In Czech). $3^{\text {rd }}$ edn. Ossis, Tábor (CZ), 580 p.

Weaver C, Wijesinha-Bettoni R, Mc Mahon D, Spence L 2013: Milk and dairy products as part of the diet. In: Muehlhoff E, Bennett A, Mc Mahon D (Eds): Milk and Dairy Products in Human Nutrition. FAO, Rome, pp. 103-206

Zamberlin Š, Antunac N, Havranek J, Samaržija D 2012: Mineral elements in milk and dairy products. Mljekarstvo 62: $111-125$

Zimmermann MB 2008: Iodine-deficiency disorders. Lancet 372: 1251-1262 